\title{
Effectiveness of Brief Educational Training on Medical Students' Attitude toward Suicide Prevention
}

\author{
${ }^{1}$ Department of Psychiatry, All India Institute of Medical Sciences, \\ Jodhpur, Rajasthan, India \\ ${ }^{2}$ Department of Psychiatry, Sri Venkateshwaraa Medical College \\ Hospital, Puducherry, India \\ ${ }^{3}$ College of Nursing, All India Institute of Medical Sciences, Jodhpur, \\ Rajasthan, India \\ ${ }^{4}$ Department of Psychiatry, All India Institute of Medical Sciences, \\ Jodhpur, India
}

Naresh Nebhinani ${ }^{1}$ Pooja Patnaik Kuppili ${ }^{2} \quad$ Mamta $^{3} \quad$ Karandeep Paul ${ }^{4}$

J Neurosci Rural Pract 2020;11:609-615

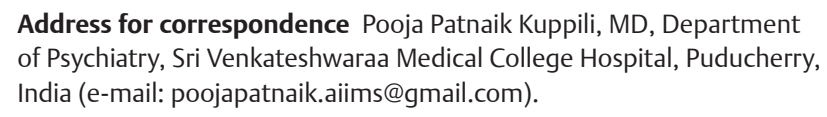

Address for correspondence Pooja Patnaik Kuppili, MD, Department of Psychiatry, Sri Venkateshwaraa Medical College Hospital, Puducherry, India (e-mail: poojapatnaik.aiims@gmail.com).

\begin{abstract}
Keywords

- medical students

- brief training

- educational intervention

- self-harm

- suicide

- suicide prevention

Objectives Medical students are future physicians, and their attitude toward suicide attempters can impact outcome of patient management and quality of care. This study aimed to assess the effects of brief educational intervention on medical students' attitude toward suicide prevention.

Materials and Methods The prospective study was conducted at a tertiary care center in northwestern India. The total enumeration method was employed to recruit 243 medical students. Attitude toward suicide prevention scale was applied before and after three hours' training on management of suicide attempters and strategies for suicide prevention.

Statistical Analysis Mean, median, standard deviation, frequencies, and percentages were calculated through descriptive statistics. Mean values were compared before and after the intervention through paired sample student's $t$-test. Chi-square test or Fischer exact test was used to compare categorical variables and $p \leq 0.05$ was set for level of significance.

Results Ten out of 14 attitudinal statements were significantly more favorable after imparting brief training on suicide prevention and management of suicide attempters. They reported lesser resentment, more responsible efforts, with greater competence and positive expectation associated with working for suicidal patients. They agreed on the need for multidisciplinary efforts for effective suicide prevention. After the intervention, they considered the possibility of suicidal ideas emerging due to the need for help, not for the purpose of attention-seeking, and instead of considering suicidal communication as individual's choice, they agreed on substantial preventability of suicide with comprehensive management. Their misconceptions were resolved to a greater extent.

Conclusion Brief educational intervention was found effective in improving their attitude toward suicide prevention. The medical curriculum should incorporate regular educational programs, suicide prevention and comprehensive assessment, and management of suicide attempters.
\end{abstract}

DOI https://doi.org/

$10.1055 / \mathrm{s}-0040-1716769$

ISSN 0976-3147.
C2020 Association for Helping

Neurosurgical Sick People
License terms

() (1) $\ominus \circledast$ 


\section{Introduction}

Suicide is associated with a significant global burden; approximately $78 \%$ of suicides occur in lower and middle-income group countries, and it is commonly associated with psychiatric illnesses. ${ }^{1}$ There has been an alarming increase in the rates of suicide among students in India, from $5.5 \%$ of total suicides in 2010 to $7.6 \%$ in 2018.,3 Patient-related factors such as poor help-seeking, stigma, and healthcare-related factors such as lack of skills in managing suicidal patients are some important barriers to prevention of suicide. ${ }^{4}$ Doctors play a pivotal role in the management of suicide attempters as well as the prevention of suicide. However, a significant proportion of doctors hold an unfavorable attitude toward suicide. Limited focus on suicide in the medical curriculum, stigma, and deficit in skills leading to decreased confidence are some of the reasons purported to be responsible for the negative beliefs about suicide. 5,6

It was found that health personnel in Australia who had exposure to suicide prevention had a significantly better attitude toward suicide prevention. ${ }^{7}$ In Japan, it was found that a positive attitude toward suicide prevention and reduced critical comments about suicide was associated with higher clinical experience. ${ }^{8} \mathrm{~A}$ study on final-year medical students from Haryana found that almost two-thirds of the respondents had poor awareness about suicide, and only half had a favorable attitude toward suicide prevention. ${ }^{9,10}$ Similarly, $50 \%$ of nursing students in north India and Jodhpur harbored a positive attitude toward the prevention of suicide. ${ }^{11,12}$ The majority of these respondents in all the above studies had no exposure to any programs focusing on management or prevention of suicide.

There is limited literature about the efficacy of suicide prevention program from the Indian setting. There is only a single study done on 32 second-year medical students, which had assessed the effect of a training program (as part of clinical posting) on knowledge and attitude toward curbing suicide. ${ }^{13}$ With this background, the current study was aimed to assess the effect on the attitude of medical students toward suicide prevention through a brief training on the management of suicide attempters.

\section{Materials and Methods}

\section{Study Universe}

After approval from the college authorities, the study was conducted at a tertiary care teaching center in northwestern India. The study was of a prospective study design. The total enumeration method was used to recruit the students. All the students belonging to the first, second, third, and final years of the MBBS course, who had attended the medical college on the day of the study, were recruited for the study. The informed consent of the students was taken, and the study procedure was explained on the first day. The intervention was delivered in the college lecture theater for a period of 3 days. Sociodemographic data was collected at baseline. The scale to assess the attitude about suicide prevention was administered at baseline and after the intervention.

\section{Measures}

A semistructured proforma was administered to assess sociodemographic details, past experience of patients with suicidal ideation or attempts, family, or past history of psychiatric illness. The attitude of medical students about the prevention of suicide was assessed by attitude toward suicide prevention scale, ${ }^{14}$ which has 14 items on a five-point Likert scale with responses from strongly disagree (1) to strongly agree (5). It has been used in Indian studies and has been found to not only have high test-retest reliability but also good internal consistency. ${ }^{9}$

\section{Intervention}

The brief training of 3-hour duration on the management of suicide attempters was based on the manual provided by World Health Organization titled "Preventing suicide: a resource for primary health care workers," which had been earlier used for a study on brief training on suicide prevention in the general healthcare setting. ${ }^{15,16}$ The components consisted of epidemiological aspects of suicide, causes, warning signs, management, and prevention of suicide. The format of the intervention involved lectures and workshop conducted by a team of psychiatrists and psychologists.

\section{Statistical Analysis}

The analysis was performed using SPSS 20 for Windows (Chicago, Illinois, USA). Mean, median, standard deviation, frequencies, and percentages were calculated through descriptive statistics. The mean scores of the students, pre- and postintervention on each of the items on the "attitude toward suicide prevention scale," were calculated by summing up the values assigned to each of the attitudinal responses, ranging from 1 to 5 and dividing by the number of subjects.

Furthermore, the median response was determined by the most common response amongst the condensed three response types, that is, disagree (strongly disagree/disagree), uncertain, and agree (strongly agree/agree). Mean scores before and after the intervention were compared by paired sample student's $t$-test, and categorical variables were compared by the Chi-square test. In the case of cells with less than 5, Fischer exact test was used and $p \leq 0.05$ was kept as level of significance in all the statistical tests.

\section{Results}

At baseline, 243 students were enrolled with the help of convenient sampling. Majority of students belonged to the finalyear MBBS course $(n=85)$ followed by second-year $(n=62)$, third-year $(n=57)$ and first-year $(n=39)$. At the end of the study, postintervention data on their attitude toward suicide prevention was available from 195 students, who had completed the intervention.

The sociodemographic data of the sample is documented in -Table 1. The typical profile of the subjects was that of a male belonging to nuclear family residing in urban area. Nearly one-third of students had experience in managing patients with suicidal ideation. 
Table 1 Sociodemographic profile of the students

\begin{tabular}{|l|l|l|l|}
\hline \multirow{2}{*}{ Variable } & Baseline data $(N=243)$ & Postintervention data $(N=195)$ & Statistics \\
\cline { 2 - 4 } & Mean (SD)/ N (\%) & Mean (SD)/ $(\%)$ & $t$ test/ Chi square/FET \\
\hline Age (years) & $19.74(1.82)$ & $19.52(2.32)$ & $\begin{array}{l}t=1.97 \\
p=0.99\end{array}$ \\
\hline Male gender & $170(70 \%)$ & $130(66.7 \%)$ & $\begin{array}{l}X^{2}=0.40 \\
p=0.53\end{array}$ \\
\hline Nuclear family & $188(77 \%)$ & $147(75.4 \%)$ & $\begin{array}{l}X^{2}=0.01 \\
p=0.99\end{array}$ \\
\hline Urban residence & $177(72.8 \%)$ & $143(73.3 \%)$ & $\begin{array}{l}X^{2}=0.01 \\
p=0.90\end{array}$ \\
\hline Past history of psychiatric illness & $3(1.2 \%)$ & $7(3.6 \%)$ & FET; $p=0.11$ \\
\hline $\begin{array}{l}\text { Family history of psychiatric illness } \\
\text { History of managing patients with suicidal } \\
\text { ideation }\end{array}$ & $78(32.1 \%)$ & $7(3.6 \%)$ & $\begin{array}{l}X^{2}=0.24 \\
p=0.62\end{array}$ \\
\hline $\begin{array}{l}\text { History of managing patients with suicidal } \\
\text { attempt }\end{array}$ & $45(18.5 \%)$ & $64(32.8 \%)$ & $\begin{array}{l}X^{2}=0.02 \\
p=0.87\end{array}$ \\
\hline
\end{tabular}

Abbreviations: FET, Fischer exact test; SD, standard deviation.

The attitude of the students before the intervention is represented in - Table 2 . At the baseline, the majority of the respondents had a positive attitude toward the prevention of suicide with regard to most of the questions.

The attitude of the students after the intervention is represented in - Table $\mathbf{3}$. The attitude strengthened further after the intervention, from (dis)agree to strongly (dis)agree. The students reported even lesser resentment, more responsible efforts, ease, competence, and expectancy on working for suicidal patients after the intervention.

The comparison of attitude of the students before and after the intervention is represented in - Table 4. After the intervention, they considered the possibility of suicidal ideas emerging due to the need for help, not for the purpose of attention-seeking, and instead of considering suicidal communication as individual's choice, they agreed on substantial preventability of suicide with comprehensive management. Their misconceptions were resolved to a greater extent.

\section{Discussion}

The index study found that the brief intervention could improve the medical students' attitude toward suicide prevention. The study also demonstrated the feasibility of carrying out a brief intervention for undergraduate medical students. A randomized controlled trial on brief intervention (as a part of project WHO Multisite Intervention Study on Suicidal Behaviors (SUPRE-MISS), similar to our study, delivered to suicide attempters and conducted in five countries demonstrated a significant reduction in deaths due to suicide. ${ }^{17}$

At the baseline, the majority of the students reported a positive attitude toward suicide prevention. This could be because nearly one-third of the respondents had clinical experience in managing patients with suicidal ideation. The greatest improvement in attitude was found in the statement that, "People are serious about committing suicide. They do not tell anyone." About $24 \%$ and $73.8 \%$ of the students disagreed (either strongly disagree or disagree) to this statement before and after the intervention, respectively.

Significant improvement was noted in areas such as competence in assessment of suicidal ideation, attitude toward efforts for prevention of suicide, and attributes of patients with suicidal ideation. The study finding is in concordance with several studies. A study assessing the effectiveness of brief intervention of suicide prevention for clinical and nonclinical general hospital frontline professionals noted that the intervention resulted in improvement in attitude with the greatest improvement for the domain of competency. ${ }^{16}$ In Hong Kong, an intensive training about prevention of suicides consisting of decreasing stigmatization, negative appraisal, and enhancing sensitivity regarding suicide was performed for 2 weeks for third and final-year medical undergraduates. ${ }^{18}$ Positive attitude toward suicide was noted following the intervention. ${ }^{18}$ In the USA, significant improvement in suicidal risk assessment skills was noted in students who received case scenario-based training. ${ }^{19}$

However, an Indian study found that there was limited improvement in attitude about suicide prevention after the intervention, which consisted of interactive sessions, clinical interview, and role play supervised by a psychiatrist, and the majority of the respondents were not comfortable in assessing patients with suicidal ideation. This difference in findings could be due to difference in the baseline attitude of the students, which was largely positive, experience in managing patients with suicidal ideation, shorter duration of intervention as well as variation in mode of delivery of intervention. $^{8}$

Our study was bound by certain limitations. The study findings cannot be generalized to other settings, as it was conducted in a single college in northwestern India. The attitude was assessed immediately at the end of the intervention. Studies with a longer follow-up period are warranted. Furthermore, the sample was predominantly male, and one previous study noted that girls had a greater negative attitude than boys about 
Table 2 Attitude of the students before the intervention

\begin{tabular}{|c|c|c|c|c|c|c|c|}
\hline $\begin{array}{l}\text { S. } \\
\text { No. }\end{array}$ & Item & $\begin{array}{l}\text { Median } \\
\text { response }\end{array}$ & $\begin{array}{l}\text { Strongly } \\
\text { disagree }\end{array}$ & Disagree & Neutral & Agree & Strongly agree \\
\hline 1 & $\begin{array}{l}\text { Resentment on asking } \\
\text { for suicide prevention }\end{array}$ & Disagree & $62(25.5 \%)$ & 88 (36.2\%) & 45 (18.5\%) & $39(16 \%)$ & $9(3.7 \%)$ \\
\hline 2 & $\begin{array}{l}\text { I am not responsible for } \\
\text { suicide prevention }\end{array}$ & Disagree & $136(56 \%)$ & 93 (38.3\%) & $10(4.1 \%)$ & $1(0.4 \%)$ & $3(1.2 \%)$ \\
\hline 3 & $\begin{array}{l}\text { With raising funds for } \\
\text { health services, there will } \\
\text { not be any difference in } \\
\text { suicide rate }\end{array}$ & Disagree & 34 (14\%) & 109 (44.9\%) & 64 (26.3\%) & 28 (11.5\%) & $8(3.3 \%)$ \\
\hline 4 & $\begin{array}{l}\text { I feel rewarding on work- } \\
\text { ing for suicidal patients }\end{array}$ & Agree & $1(0.4 \%)$ & $9(3.7 \%)$ & 69 (28.4\%) & 130 (53.5\%) & 34 (14\%) \\
\hline 5 & $\begin{array}{l}\text { People do not tell anyone } \\
\text { if they are serious about } \\
\text { suicide }\end{array}$ & Disagree & $15(6.2 \%)$ & 44 (18.1\%) & 55 (22.6\%) & 90 (37\%) & 39 (16\%) \\
\hline 6 & $\begin{array}{l}\text { I feel defensive on peo- } \\
\text { ple's advice on suicide } \\
\text { prevention }\end{array}$ & Disagree & 34 (14\%) & 105 (43.2\%) & 48 (19.8\%) & 55 (22.6\%) & $1(0.4 \%)$ \\
\hline 7 & $\begin{array}{l}\text { Making judgment on } \\
\text { suicide prevention is easy } \\
\text { for people not involved } \\
\text { in clinical care }\end{array}$ & Agree & $10(4.1 \%)$ & 70 (28.8\%) & 75 (30.9\%) & $82(33.7 \%)$ & $6(2.5 \%)$ \\
\hline 8 & $\begin{array}{l}\text { Suicide attempt is for } \\
\text { attention, if person sur- } \\
\text { vives after attempt }\end{array}$ & Disagree & 46 (18.9\%) & 94 (38.7\%) & 44 (18.1\%) & $36(14.8 \%)$ & $23(9.5 \%)$ \\
\hline 9 & $\begin{array}{l}\text { I think people have right } \\
\text { to take their own lives }\end{array}$ & Disagree & 96 (39.5\%) & 74 (30.5\%) & 39 (16\%) & 25 (10.3\%) & $9(3.7 \%)$ \\
\hline 10 & $\begin{array}{l}\text { One cannot prevent } \\
\text { suicide as main causes of } \\
\text { suicide are poverty and } \\
\text { unemployment }\end{array}$ & Disagree & 57 (23.5\%) & 105 (43.2\%) & $23(9.5 \%)$ & $50(20.6 \%)$ & $8(3.3 \%)$ \\
\hline 11 & $\begin{array}{l}\text { Suicide risk assessment } \\
\text { for someone makes me } \\
\text { uncomfortable }\end{array}$ & Disagree & $26(10.7 \%)$ & 131 (53.9\%) & 49 (20.2\%) & 34 (14\%) & $3(1.2 \%)$ \\
\hline 12 & $\begin{array}{l}\text { Better we utilize these } \\
\text { resources elsewhere } \\
\text { than draining on suicide } \\
\text { prevention measures }\end{array}$ & Disagree & 73 (30\%) & $113(46.5 \%)$ & $26(10.7 \%)$ & $25(10.3 \%)$ & $6(2.5 \%)$ \\
\hline 13 & $\begin{array}{l}\text { We do not have any } \\
\text { way to know that who is } \\
\text { going to commit suicide }\end{array}$ & Disagree & $27(11.1 \%)$ & $155(63.8 \%)$ & $38(15.6 \%)$ & $16(6.6 \%)$ & 7 (2.9\%) \\
\hline 14 & $\begin{array}{l}\text { What proportion of } \\
\text { suicides do you consider } \\
\text { preventable }\end{array}$ & & $\begin{array}{l}\text { Few } \\
24(9.9 \%)\end{array}$ & $\begin{array}{l}\text { Many } \\
97 \text { (39.9\%) }\end{array}$ & $\begin{array}{l}\text { Most } \\
114(46.9 \%)\end{array}$ & $\begin{array}{l}\text { All } \\
8(3.3 \%)\end{array}$ & - \\
\hline
\end{tabular}

suicide. ${ }^{9}$ Hence, our study findings could be influenced by the sociodemographic profile.

Newer teaching and learning methods such as simulation, role plays instead of traditional lecture methods, need to be adopted. ${ }^{5}$ Culture-sensitive teaching methods for prevention of suicide can help in improving skills toward suicide. There is a need for studies assessing the effectiveness of such intervention in the hospital setting by assessing the suicide rates before and after the intervention.

Brief intervention on suicide prevention can be incorporated as a part of the medical curriculum to prevent untoward suicides. This can reap rich dividends in the form of improving 
Brief Training to Medical Students' Attitudes Toward Suicide Prevention Nebhinani et al. 613

Table 3 Attitude of the students after the intervention

\begin{tabular}{|c|c|c|c|c|c|c|c|}
\hline $\begin{array}{l}\text { S. } \\
\text { No. }\end{array}$ & Item & $\begin{array}{l}\text { Median } \\
\text { response }\end{array}$ & $\begin{array}{l}\text { Strongly } \\
\text { disagree }\end{array}$ & Disagree & Neutral & Agree & Strongly agree \\
\hline 1 & $\begin{array}{l}\text { Resentment on asking } \\
\text { for suicide prevention }\end{array}$ & Disagree & 55 (28.2\%) & 112 (57.4\%) & 14 (7.2\%) & 12 (6.2\%) & $2(1 \%)$ \\
\hline 2 & $\begin{array}{l}\text { I am not responsible for } \\
\text { Suicide prevention }\end{array}$ & Disagree & 104 (53.3\%) & 87 (44.6\%) & $2(1 \%)$ & 1 (0.5\%) & 1 (0.5\%) \\
\hline 3 & $\begin{array}{l}\text { With raising funds for } \\
\text { health services there will } \\
\text { not be any difference in } \\
\text { suicide rate }\end{array}$ & Disagree & 48 (24.6\%) & 103 (52.8\%) & $30(15.4 \%)$ & $10(5.1 \%)$ & $4(2.1 \%)$ \\
\hline 4 & $\begin{array}{l}\text { I feel rewarding on work- } \\
\text { ing for suicidal patients }\end{array}$ & Agree & $1(0.5 \%)$ & $5(2.6 \%)$ & 30 (15.4\%) & 113 (57.9\%) & 46 (23.6\%) \\
\hline 5 & $\begin{array}{l}\text { People do not tell anyone } \\
\text { if they are serious about } \\
\text { suicide }\end{array}$ & Disagree & 31 (15.9\%) & 113 (57.9\%) & $21(10.8 \%)$ & $25(12.8 \%)$ & $5(2.6 \%)$ \\
\hline 6 & $\begin{array}{l}\text { I feel defensive on peo- } \\
\text { ple's advice on suicide } \\
\text { prevention }\end{array}$ & Disagree & 24 (12.3\%) & 115 (59.0\%) & $34(17.4 \%)$ & $21(10.8 \%)$ & 1 (0.5\%) \\
\hline 7 & $\begin{array}{l}\text { Making judgment on } \\
\text { suicide prevention is easy } \\
\text { for people not involved } \\
\text { in clinical care }\end{array}$ & Uncertain & $5(2.6 \%)$ & 47 (24.1\%) & 82 (42.1\%) & 55 (28.2\%) & $6(3.1 \%)$ \\
\hline 8 & $\begin{array}{l}\text { Suicide attempt is for } \\
\text { attention, if person sur- } \\
\text { vives after attempt }\end{array}$ & Disagree & 70 (35.9\%) & 77 (39.5\%) & $22(11.3 \%)$ & 19 (9.7\%) & 7 (3.6\%) \\
\hline 9 & $\begin{array}{l}\text { I think people have the } \\
\text { right to take their own } \\
\text { lives }\end{array}$ & Disagree & 79 (40.5\%) & 74 (37.9\%) & $21(10.8 \%)$ & 19 (9.7\%) & $2(1 \%)$ \\
\hline 10 & $\begin{array}{l}\text { One cannot prevent } \\
\text { suicide as main causes of } \\
\text { suicide are poverty and } \\
\text { unemployment }\end{array}$ & Disagree & 47 (24.1\%) & $116(59.5 \%)$ & 19 (9.7\%) & $12(6.2 \%)$ & $1(0.5 \%)$ \\
\hline 11 & $\begin{array}{l}\text { Suicide risk assessment } \\
\text { for someone makes me } \\
\text { uncomfortable }\end{array}$ & Disagree & 42 (21.5\%) & $121(62.1 \%)$ & $22(11.3 \%)$ & $10(5.1 \%)$ & 0 \\
\hline 12 & $\begin{array}{l}\text { Better we utilize these } \\
\text { resources elsewhere } \\
\text { than draining on suicide } \\
\text { prevention measures }\end{array}$ & Disagree & 79 (40.5\%) & 89 (45.6\%) & $14(7.2 \%)$ & 10 (5.1\%) & $3(1.5 \%)$ \\
\hline 13 & $\begin{array}{l}\text { We do not have any } \\
\text { way to know that who is } \\
\text { going to commit suicide }\end{array}$ & Disagree & 58 (29.7\%) & $121(62.1 \%)$ & $11(5.6 \%)$ & $4(2.1 \%)$ & 1 (0.5\%) \\
\hline 14 & $\begin{array}{l}\text { What proportion of } \\
\text { suicides do you consider } \\
\text { preventable }\end{array}$ & & $\begin{array}{l}\text { Few } \\
2(1 \%)\end{array}$ & $\begin{array}{l}\text { Many } \\
32(16.4 \%)\end{array}$ & $\begin{array}{l}\text { Most } \\
133(68.2 \%)\end{array}$ & $\begin{array}{l}\text { All } \\
28(14.4 \%)\end{array}$ & - \\
\hline
\end{tabular}

the competency of medical students in the management of patients with suicidal ideation; moreover, they can act as gatekeepers whenever they encounter such individual or patient. ${ }^{20}$ Positive attitudes toward prevention of suicide amongst the medical students can lead to long-term outcomes in terms of early detection and timely referral to psychiatrists.
To conclude, brief training on the management of suicide attempters is feasible and was found to be effective in improving attitude on suicide prevention among undergraduate medical students. There is a vital need for multipronged efforts for effective suicide prevention, with a comprehensive approach incorporating regular training on suicide 
Table 4 The comparison of attitude of the students before and after the intervention

\begin{tabular}{|c|c|c|c|c|}
\hline $\begin{array}{l}\text { S. } \\
\text { No }\end{array}$ & Item & Baseline score & Posttraining & $\begin{array}{l}\mathrm{t} / \mathrm{X}^{2} \\
\text { ( } p \text {-value) }\end{array}$ \\
\hline \multicolumn{5}{|c|}{ Mean (SD) } \\
\hline 1 & Resentment on asking for suicide prevention & $2.36(1.13)$ & $1.94(0.83)$ & $4.30(<0.001)$ \\
\hline 2 & I am not responsible for suicide prevention & $1.53(0.71)$ & $1.50(0.60)$ & $0.37(0.70)$ \\
\hline 3 & $\begin{array}{l}\text { With raising funds for health services there will not be } \\
\text { any difference in suicide rate }\end{array}$ & $2.45(0.98)$ & $2.07(0.88)$ & $4.21(<0.001)$ \\
\hline 4 & I feel rewarding on working for suicidal patients & $3.77(0.74)$ & $4.02(0.73)$ & $-3.44(0.001)$ \\
\hline 5 & $\begin{array}{l}\text { People do not tell anyone if they are serious about } \\
\text { suicide }\end{array}$ & $3.39(1.13)$ & $2.28(0.96)$ & $10.78(<0.001)$ \\
\hline 6 & $\begin{array}{l}\text { I feel defensive on people's advice on suicide } \\
\text { prevention }\end{array}$ & $2.52(1.00)$ & $2.28(0.83)$ & $2.68(0.008)$ \\
\hline 7 & $\begin{array}{l}\text { Making judgment on suicide prevention is easy for } \\
\text { people not involved in clinical care }\end{array}$ & $3.02(0.94)$ & $3.05(0.86)$ & $-0.39(0.69)$ \\
\hline 8 & $\begin{array}{l}\text { Suicide attempt is for attention, if person survives } \\
\text { after attempt }\end{array}$ & $2.57(1.22)$ & $2.06(1.09)$ & $4.60(<0.001)$ \\
\hline 9 & I think people have right to take their own lives & $2.08(1.14)$ & $1.93(0.99)$ & $1.48(0.13)$ \\
\hline 10 & $\begin{array}{l}\text { One cannot prevent suicide as main causes of suicide } \\
\text { are poverty and unemployment }\end{array}$ & $2.37(1.14)$ & $1.99(0.79)$ & $3.88(<0.001)$ \\
\hline 11 & $\begin{array}{l}\text { Suicide risk assessment for someone makes me } \\
\text { uncomfortable }\end{array}$ & $2.41(0.90)$ & $2.0(0.73)$ & $5.15(<0.001)$ \\
\hline 12 & $\begin{array}{l}\text { Better we utilize these resources elsewhere than drain- } \\
\text { ing on suicide prevention measures }\end{array}$ & $2.09(1.01)$ & $1.82(0.88)$ & $2.92(0.004)$ \\
\hline 13 & $\begin{array}{l}\text { We do not have any way to know that who is going to } \\
\text { commit suicide }\end{array}$ & $2.26(0.85)$ & $1.82(0.67)$ & $6.0(<0.001)$ \\
\hline 14 & $\begin{array}{l}\text { What proportion of suicides do you consider } \\
\text { preventable }\end{array}$ & $60 \%$ & $82 \%$ & $59.39(<0.001)$ \\
\hline
\end{tabular}

prevention and comprehensive management of suicide attempters in the medical curriculum.

\section{Note}

The research has been performed conforming to the Declaration of Helsinki.

\section{Funding}

None.

\section{Conflict of Interest}

None declared.

\section{References}

1 Bachmann S. Epidemiology of suicide and the psychiatric perspective. Int J Environ Res Public Health 2018;15(7):1425

2 Ponnudurai R. Suicide in India - changing trends and challenges ahead. Indian J Psychiatry 2015;57(4):348-354

3 National Crime Records Bureau. Accidental deaths and suicides in India. Ministry of Home Affairs, Government of India, 2018: 195-209

4 Leavey G, Mallon S, Rondon-Sulbaran J, Galway K, Rosato M, Hughes L. The failure of suicide prevention in primary care: family and GP perspectives - a qualitative study. BMC Psychiatry 2017;17(1):369

5 Gramaglia C, Zeppegno P. Medical students and suicide prevention: training, education, and personal risks. Front Psychol 2018;9:452
6 Hawgood JL, Krysinska KE, Ide N, De Leo D. Is suicide prevention properly taught in medical schools? Med Teach 2008;30(3):287-295

7 Brunero S, Smith J, Bates E, Fairbrother G. Health professionals' attitudes towards suicide prevention initiatives. J Psychiatr Ment Health Nurs 2008;15(7):588-594

8 Sato R, Kawanishi C, Yamada T, et al. Knowledge and attitude towards suicide among medical students in Japan: preliminary study. Psychiatry Clin Neurosci 2006;60(5):558-562

9 Nebhinani N, Chahal S, Jagtiani A, Nebhinani M, Gupta R. Medical students' attitude toward suicide attempters. Ind Psychiatry J 2016;25(1):17-22

10 Nebhinani N, Jagtiani A, Chahal S, Nebhinani M, Gupta R. Medical students' attitude toward suicide prevention: an exploratory study from North India. Med J DY Patil Univ 2017; 10:277-280

11 Nebhinani N, Mamta, Gaikwad AD, Tamphasana L. Nursing students' attitude toward suicide prevention. Ind Psychiatry J 2013;22(2):114-117

12 Nebhinani M, Nebhinani N, Tamphasana L, Gaikwad AD. Nursing students' attitude towards suicide attempters: a study from rural part of Northern India. J Neurosci Rural Pract 2013;4(4):400-407

13 Desai ND, Chavda P, Shah SH, Shah N, Shah SN, Sharma E. A novel approach to suicide prevention - Educating when it matters. Ind Psychiatry J 2018;27(1):115-123

14 Appleby L, Morriss R, Gask L, et al. An educational intervention for front-line health professionals in the assessment and management of suicidal patients (The STORM Project) Psychol Med 2000;30(4):805-812 
15 World Health Organization, Preventing Suicide: A Resource for Primary Health Care Workers. Geneva: Department of Mental Health; 2000

16 Berlim MT, Perizzolo J, Lejderman F, Fleck MP, Joiner TE. Does a brief training on suicide prevention among general hospital personnel impact their baseline attitudes towards suicidal behavior? J Affect Disord 2007;100(1-3):233-239

17 Fleischmann A, Bertolote JM, Wasserman D, et al. Effectiveness of brief intervention and contact for suicide attempters: a randomized controlled trial in five countries. Bull World Health Organ 2008;86(9):703-709
18 Yousuf S, Beh PS, Wong PW. Attitudes towards suicide following an undergraduate suicide prevention module: experience of medical students in Hong Kong. Hong Kong Med J 2013;19(5):377-385

19 Madson L, Vas CJ. Learning risk factors for suicide: A scenario-based activity. Teach Psychol 2003;30:123-126

20 Menon V, Subramanian K, Selvakumar N, Kattimani S. Suicide prevention strategies: An overview of current evidence and best practice elements. Int J Adv Med Health Res 2018;5:43-51 